\title{
So You Want to Be a Teacher: What Are Your Reasons?
}

\author{
Ab Rahim Bakar ${ }^{1}$, Shamsiah Mohamed ${ }^{1}$, Asmawati Suhid ${ }^{1} \&$ Ramlah Hamzah $^{1}$ \\ ${ }^{1}$ Faculty of Educational Studies, Universiti Putra Malaysia, Selangor, Malaysia \\ Correspondence: Ab Rahim Bakar, Universiti Putra Malaysia, 43400 Serdang, Selangor, Malaysia. Tel: \\ 603-8946-8110. E-mail: abrahimbakar@yahoo.com
}

\author{
Received: July 4, 2014 Accepted: August 5, 2014 Online Published: October 29, 2014 \\ doi:10.5539/ies.v7n11p155 \\ URL: http://dx.doi.org/10.5539/ies.v7n11p155
}

\begin{abstract}
This study explored student teachers views of factors influencing them to choose teaching as a career. A total of 600 student teachers completed a questionnaire. They were asked to rate the importance of 25 factors in influencing their choice of teaching as a career. Using Factor Analysis, we categorized the 25 factors into three main factors (Intrinsic, Extrinsic, and Altruistic). We found that of the three factors, altruistic motivation seems to be more dominant (Mean=6.07) than intrinsic (Mean=5.72), and extrinsic motivation (Mean=5.4). We compared the views expressed by those who were not considering teaching and those who were considering teaching as a career option in relation to factors important in influencing their decisions. We also compared the importance of the factors based on gender. For all the groups regardless of gender or career option, altruistic factors were rated more important than intrinsic and extrinsic factors.
\end{abstract}

Keywords: student teachers, motivation for teaching choice, factors influencing teaching choice, teaching as a career

\section{Introduction}

Teaching is a noble profession and has helped to shape many nations. In fact, as explained by Richardson and Watt (2006), Governments around the world recognize that quality teachers and teaching are central to the development and maintenance of an intelligent, informed people. The Prime Minister of Malaysia, for example, has stated in the Malaysia Education Blue Print 2015-2025 that education is a major contributor to the growth of Malaysia's social and economic capital. As such according to the Minister of Education, Malaysia, the Government is committed to transform the Malaysia's education system to ensure students are holistically equipped to allow them to succeed in the $21^{\text {st }}$ century, with all the opportunities and challenges that this new era presents (MOE, 2013). To ensure this aspiration is achieved, Malaysia needs quality teachers.

Malaysia, unlike many other countries does not experience a shortage of teachers. In fact, we have a surplus in some areas. However, according to OECD (2005), several Western countries show a recurring shortage of teachers. Recruiting and retaining teachers prove to be very challenging and problematic in many countries. Countries, such as England, for example, 40 percent of those who start teacher education never become teachers (Kyriacou \& Kunc, 2007). Moreover, 40 percent of the 60 percent who completed teacher education in England left the profession within the first five years (Kyriacou \& Kunc, 2007). Australian research estimates that 30 percent leave the profession during the same period (Watt \& Richardson, 2007). Ingersoll (2003) also reports that only 48 percent of American teachers who graduated in 1993 were teaching five years after graduation. In Malaysia, very seldom teachers quit the teaching post. In fact, there are more graduates wanted to become teacher compared to the number of teaching post available. One unique reason why beginning teachers in Malaysia do not leave the profession is because learning to become a teacher is sponsored by the Government either through scholarship or education loan. If they are given a scholarship they have a contract to serve the Ministry of Education for at least seven years. Another reason is that teaching in Malaysia is a secured job with many benefits provided by the Government. Therefore, the phenomena of "hired today, gone tomorrow" as postulated by Feng (2005) and Marvel et al. (2007) is not happening in Malaysia an may not happen at all in the coming future.

\section{Why We Need to Study the Motivational Aspect of Career Choice?}

Researchers and policy-makers are interested in understanding teachers' motivation to choose and pursue a teaching career due to the belief that motivation is linked to teaching quality, engagement, and commitment 
towards the profession (e.g., de Jesus \& Lens, 2005) and the links between teachers' motivation and teaching quality are beginning to be found across a range of cultures (OECD, 2005). In studies on motivation for teaching, it is usual to distinguish between intrinsic, extrinsic and altruistic reasons for selecting the profession (Kyriacou \& Coulthard, 2000; Moran et al., 2001). In fact, factors influencing prospective teachers to choose teaching as their profession is categorised into intrinsic, extrinsic and altruistic factors. Teachers with intrinsic motivation tend to focus on instruction and the activity related to the business itself. They choose teaching because they like the job and the joy of teaching is the driving force that makes them stay in the profession. On the other hand, the extrinsically motivated teachers choose the profession because of benefits related to the job such as salary, holidays or other external rewards. The altruistically motivated teachers view teaching as a profession that enable them to contribute to the society such as by being a part of young peoples' growth and development.

It is significant to have employees who are intrinsically motivated. Research in educational settings suggests that even students who are high in intrinsic motivation are more tenacious, self-driven, and autonomous (Deci \& Ryan, 2000). Furthermore, the review by Gagne and Deci (2005) suggests that employees high in intrinsic motivation are more involved in their jobs and demonstrate greater goal attainment than those less intrinsically motivated. Individuals who are intrinsically motivated are willing to work on tasks because they find them enjoyable and interesting. A larger number of roles and responsibilities may be welcomed by employees with high levels of intrinsic motivation who see more meaning in their work and are more self-driven and autonomous, and thus result in an increased work effort. Also, as employees high in intrinsic motivation are more persistent and interested in their work, their work quality should increase to higher levels. Employees with low levels of intrinsic motivation, on the other hand, may not have the drive and engagement to work more independently because they lack purpose or meaning in their jobs, have less persistence, and are less self-driven. Intrinsic motivation generally referred to as the motive that keeps individuals at a task through its own inherent qualities (Ryan \& Deci, 2000). Elements of intrinsic motivation include enthusiastic task involvement, desire to experience adventure and novelty, striving for excellence in one's work, trying to understand something and wishing to improve, and goal direction (that is, seeing a purpose in what one is doing). Studies (e.g., Davis \& Wilson 2000; Fokkens-Bruinsma \& Canrinus, 2012) have shown that teachers' motivation has been found to be significantly related to teachers' job satisfaction. Spear, Gould, and Lee (2000) find in their review of research in England and Wales that intrinsic and altruistic motivations dominate the reasons for entering the profession among prospective teachers. Studies in Australia indicate that personal fulfillment, the desire to work with young children and to make a difference in their life and the opportunity to experience a meaningful engagement with the subject of their choice are the three main motivational factors (Manuel \& Brindley, 2005; Manuel \& Hughes, 2006).

Teaching is viewed as a demanding and stressful profession (Stoeber \& Rennert, 2008). Even then, there is a growing body of evidence suggesting that those who are educationally well prepared for teaching seem to enjoy the profession and intend to remain longer than those who became qualified through shorter programs (Darling-Hammond, 2010; Darling-Hammond et al., 2002). As discovered in studies by E. Skaalvik and S. Skaalvik (2008), one third of the teachers would choose another profession if they could choose again. Studies show that new teachers' low commitment to the profession is reflected by high attrition rates (Jalongo \& Heider, 2006). Teacher commitment is defined by Coladarci (1992) as the degree of psychological attachment to the teaching profession. Occupational commitment refers to the level of attachment to, or desire to work in, a particular career role (Hackett, Lapierre, \& Hausdorf, 2001). Occupational commitment has also been referred to as professional commitment, career commitment, and professionalism (Hackett et al., 2001). Occupational commitment leads to action, including motivated behaviours such as effort and perseverance, and negative outcomes, like work avoidance, protest, defiance, and quitting (Meyer et al., 2004). Therefore, it is assumed that those who go into teaching with high intrinsic and altruistic factors may be highly committed to the profession will perform efficiently and effectively.

In a large scale Australian study, Richardson and Watt (2006) found that the highest rated motivations for having chosen teaching by prospective Australian teachers included perceived teaching abilities, the intrinsic value of teaching, and the desire to make a social contribution, shape the future, and work with children/teenagers. In a study on the Turkish prospective teachers' motivations for teaching, it was found that intrinsic career value, salary, societal status, societal influences, working with children/adolescents, and making social contribution were among the most significant factors that affected their choices for teaching (Y. Boz \& N. Boz, 2008). Personal fulfillment, working with young people, working conditions, lifestyle, and professional status were found to be among the most influential factors affecting Australian prospective teachers' motivations for teaching (Manuel \& Hughes, 2006). According to Wang (2004), prior teaching experiences, cultural beliefs about teaching, 
gaining social status, and favorable working conditions influence Taiwanese prospective teachers' motivations for teaching. According to OECD (2005), most frequent reasons for career choice among teachers was a desire to work with children and adolescents, together with the potential for the business to provide for intellectual fulfillment, and a means by which to make a social contribution.

\section{Objectives}

The aim of the study was to ascertain the factors that may influence student teachers to take teaching as their career choice and to determine if these factors differ as a function of gender and career choice.

\section{Methods}

The present study used a survey research method.

\subsection{Sample and Sampling}

The population of the study consisted of student teachers who were under-going a four-year teacher training program at Higher Public Universities in Malaysia. We sent questionnaires to 600 (25\% male and $75 \%$ female) selected student teachers at nine public universities.

\subsection{Instrument}

To assess factors that may influence student teachers to take teaching as their future profession, we adapt the FIT-Choice Scale by Watt and Richardson (2007), 'Reasons for Entering Teaching by Saban (2003), 'Teacher Trainee's Motives (Yong, 1995). Our instrument contains 25 items measured on a 7-point Likert scale ranging from: 1 (Not at all important) to 7 (Extremely important). We asked them "How important are these reasons in influencing you to become a teacher?" and student teachers were asked to rank the importance of those reasons on a 7-point Likert-scale. The instrument was pilot-tested with student teachers who were not selected to participate in the survey. The reliability coefficient of the instrument was 0.94 .

\section{Findings}

\subsection{Demographic Characteristics of the Respondents}

A total of 600 student teachers participated in the study and all of them are final year students. Their academic performances were very good with a mean CGPA of 3.4 out of 4.0. The majority of them were really satisfied with the choice of being in the teacher education program (Mean=4.39, $\mathrm{SD} .=0.61$ ) and the majority of them believe that by being in the program, it fits with their ambition to become a teacher (Mean $=4.40, \mathrm{SD} .=0.65$ ). However, we also found a small percentage of them $(11.7 \%)$ would shift to other programs if they have the opportunity to do so. The survey also showed that $8.5 \%$ of student teachers do not plan to move into teaching. In terms of knowledge about teaching profession, the study indicated that they don't really have very much knowledge about the profession (Mean=3. 64, SD. $=0.62$ ). We asked them about their future educational plan. It showed that $67 \%$ of them will pursue their study up to doctoral level and $25.2 \%$ will finish at a master degree level.

\subsection{Reasons for Choosing Teaching a Career}

The instrument we used to measure reasons for choosing teaching as a profession contains 25 items. We run Factor Analysis to categorize the 25 possible factors into 3 main factors (extrinsic, intrinsic, and altruistic) to be in-line with the literatures that say these are three possible main reasons why people choose certain occupations. We also looked at the Scree plot as the basis for this categorization and based on the Scree plot, there are three possible main factors than explain reasons for choosing teaching. These three factors accounted for $52.9 \%$ of the variable variance. Intrinsic factor accounted for $20.88 \%$, extrinsic factor accounted for $16.39 \%$, and altruistic factor accounted for $15.63 \%$ of the variance explained. Of the three factors, altruistic motivation seems to be more dominant (Mean=6.07) than intrinsic motivation (Mean=5.72), and extrinsic motivation (Mean=5.4). It was found that $55 \%$ of the respondents obtained a score above the mean for intrinsic motivation. With regard to extrinsic motivation, $51 \%$ of the respondents scored above the mean and $51 \%$ of the respondents scored above the mean as well for altruistic motivation. We also found that regardless of gender, altruistic motive was rated as more important by both male and female student teachers in influencing their choice compared to other factors. To them extrinsic factors is not as important as intrinsic factors (Table 2). Similarly, an analysis was done to determine if the motivating factors differ as a function of career option. It was found that altruistic factor plays a bigger role in selecting teaching as a profession. Those who plan to go into teaching had a significantly higher mean score in all the factors (Table 2) compared to those who do not plan to move into teaching. 
Table 1. Reasons for choosing teaching as a profession

\begin{tabular}{|c|c|c|c|}
\hline & \multicolumn{3}{|c|}{ Factors } \\
\hline & Intrinsic & Extrinsic & Altruistic \\
\hline \multicolumn{4}{|l|}{ Intrinsic $($ Mean=5.70; SD. $=.83)$} \\
\hline Teaching suit my personality & .747 & & \\
\hline I like teaching & .739 & & \\
\hline I always wanted to be a teacher & .729 & & \\
\hline I admire the teaching job & .723 & & \\
\hline I am interested in teaching & .680 & & \\
\hline I have the skills to be a good teacher & 649 & & \\
\hline I have the qualities of a good teacher & .602 & & \\
\hline I like working with children & .532 & & \\
\hline I have the emotional and psychological strength to be a teacher & .521 & & \\
\hline \multicolumn{4}{|l|}{ Extrinsic $($ Mean=5.40; SD.=.88) } \\
\hline Teaching has many fringe benefits & & .794 & \\
\hline Teachers are paid well & & .694 & \\
\hline Teaching has many holidays & & .667 & \\
\hline Teaching provides a clear career path & & 648 & \\
\hline Teaching is a secured job & & 628 & \\
\hline A teacher is highly respected by the society & & .594 & \\
\hline By being a teacher I can improve my social status & & .576 & \\
\hline Teaching allows more time for family & & .481 & \\
\hline My family encourage me to choose a teaching position & & .410 & \\
\hline \multicolumn{4}{|l|}{ Altruistic $($ Mean=6.07; SD.=.69) } \\
\hline Teaching allows me to influence the next generation & & & .715 \\
\hline Teaching allows me to provide social service to the society & & & .668 \\
\hline Teaching allows me to raise the ambitions of under-privileged youths & & & .619 \\
\hline $\begin{array}{l}\text { By being a teacher, I can bring an impact on children and adolescents' } \\
\text { future }\end{array}$ & & & .617 \\
\hline By being a teacher I can help the young to live a meaningful life & & & .603 \\
\hline I want to stimulate children and adolescents intellectual thoughts & & & .577 \\
\hline Teaching allows me to shape the child and adolescents future & & & .545 \\
\hline
\end{tabular}

Table 2. Means and standard deviations of factors by gender and career option

\begin{tabular}{ccccccccc}
\hline \multirow{2}{*}{ Factors } & \multicolumn{2}{c}{ Male } & \multicolumn{2}{c}{ Female } & \multicolumn{2}{c}{ Will teach } & \multicolumn{2}{c}{ No, Won't teach } \\
\hline & Mean & SD & Mean & SD & Mean & SD & Mean & SD \\
Altruistic & 6.01 & .68 & 6.09 & .69 & 6.12 & .66 & 5.52 & .81 \\
Intrinsic & 5.63 & .80 & 5.74 & .80 & 5.78 & .76 & 4.98 & .90 \\
Extrinsic & 5.29 & .98 & 5.44 & .85 & 5.43 & .88 & 5.07 & .82 \\
\hline
\end{tabular}




\section{Discussion and Conclusion}

Other countries (example USA, UK, Ireland, Australia and many more) are experiencing the shortage of teachers due to the high attrition rate, retirement of older teachers, and lesser number of university graduates applies for the teaching positions. Nevertheless, the situation in Malaysia is not like many other countries in the world. Teaching profession in Malaysia is a choice of many university graduates as proven with large number of applicants for the few vacancies available and teacher education programs are highly sought after by high school graduates. Even though Malaysia does not confront the teacher shortage problem, the study is deemed necessary to ensure the entrants into the teaching profession or teacher education programs do have the right reasons for their choice. We want the right people to be in the teaching profession to enhance the quality of teaching because the underlying aims of education are to equip students with all the necessary knowledge, attitudes, and skills to be successful in life and quality teachers is the main ingredient to satisfy these objectives.

The present study investigates the factors students teachers at Malaysian Public Universities felt had influenced their decisions to choose teaching as a career option. We constructed 25 possible reasons and asked student teachers to rate these reasons on a 7-point Likert-scale. These 25 factors were categorized into three main factors (Intrinsic, Extrinsic, and Altruistic) based on Factor Analysis. Our analysis shows that altruistic factors (example: it allows me to influence the next generation) seemed to be the most dominant factors influencing them to choose teaching as a career choice, followed by the intrinsic factors (example: teaching suit my personality) and extrinsic factors (example: teaching has many fringe benefits). In fact, it is the most dominant factors for both male and female group and well as for those who decide to go into teaching or not to go into teaching. The finding was similar to the study by Saban (2003) who also found that student teachers in Turkey rated altruistic factors as more important than intrinsic and extrinsic factors when deciding to choose teaching as their profession. However, the present study contradict Saban's finding that extrinsic factors were more important than intrinsic factors. In our study, we found that intrinsic is more important than extrinsic factors. Studies in other parts of the world also showed that altruistic factors were consistently ranked as more important than other factors when making the decision to enter teaching profession. In a study by Bastic (2000) it showed that for Jamaica sample, extrinsic factors were more dominant in choosing teaching than intrinsic and altruistic factors. Even for Malaysian sample, it also showed that extrinsic motivation was the main factors that lead student teachers to choose teaching as a vocation. This was found by Abdullah (2002) using a sample of 265 student teachers from one university in Malaysia. He found that $45 \%$ of the respondents rated extrinsic factor, $34.2 \%$ rated intrinsic factors, and $24.8 \%$ rated altruistic motives as the factors influencing them to choose teaching as a profession. However, in another study on Malaysian sample, Azman (2013) found that student teachers choose teaching as a career because of altruistic and intrinsic reasons. A study in Slovenija by Krecic and Grmek (2005) showed that self-realization was the top reason for choosing teaching, followed by altruistic and material reasons. A study by Moran et al. (2001) also demonstrated that intrinsic motivation seemed to be the most influential factors cited by teacher education students in Ireland in influencing their choice to choose teaching. Similarly, a study by Sinclair (2008) in Australia using 211 student teachers revealed that intrinsic factors have a greater influence than extrinsic factors over their decision to take up teaching position. In a study by Low et al. (2011) on pre-service teacher in Singapore, they found that the main reasons to go into the teaching profession fell into altruistic (41\%), intrinsic (55\%) and extrinsic (3\%). Like other pre-service teachers in Singapore rated Intrinsic factors as most influential that make them choose to enter the teaching profession.

The findings of the present research and other clearly shows that teachers enter the teaching profession for a very good reason, that is, they want to be a teacher and they want to serve the society. Thus, other factors such as: monetary reward (Mean=5.1) and fringe benefits (Mean=5.2), and long holidays (Mean=4.9) were not significant. The present study sheds an important light that needs to be taken into consideration by the Ministry of Education Malaysia. Since teachers enter the teaching profession for intrinsic and altruistic reasons, the teaching conditions such as class size, work environment, and job responsibility has to be amended. It is reported in the Blue Print that daily teaching hours of Malaysian teachers in primary schools are very low (2.4-2.5 hours) compared to other countries such as New Zealand (5 hours), Singapore (3.8 hours), and South Korea (4.1 hours). Their teaching hours are also very low at the secondary school comparing to other countries. The question remains, what do we teachers do? Are they made to do non-teaching job? If they are built to perform a non-teaching job, there will be an erosion of motivation to teach among our teachers and it will affect the quality of instruction in Malaysian schools.

\section{References}

Abdullah, M. Y. (2002). Motif memilih profession perguruan di Sabah (pp. 350-361). Prosiding Seminar Profesion Pergrurun: Cabaran Pendidikan Masa Kini, Fakulti Pendidikan, Universiti Kebangsaan Malaysia. 
Azman, N. (2013). Choosing teaching as a career: Perspectives of males and female Malaysian student teachers in training. European Journal of Education, 36(1), 113-130.

Bastic, T. (2000). Why teacher trainees choose the teaching profession: Comparing trainees in metropolitan and developing countries. International Review of Education, 46(3/4), 343-439. http://dx.doi.org/10.1023/A:1004090415953

Boz, Y., \& Boz, N. (2008). Kimya ve matematik öğretmen adaylarının öğretmen olma nedenleri [Prospective chemistry mathematics teachers' reasons for choosing teaching as a profession] Kastamonu Ĕgitim Dergisi-Kastamonu Education Journal, 16(1), 137-144.

Coladarci, T. (1992). Teachers' sense of efficacy and commitment to teaching. Journal of Experimental Education, 60(4), 323-337. http://dx.doi.org/10.1080/00220973.1992.9943869

Darling-Hammond, L. (2010). Teacher education and the American future. Journal of Teacher Education, 61(1\&2), 35-47. http://dx.doi.org/10.1177/0022487109348024

Darling-Hammond, L., Chung, R., \& Frelow, F. (2002). Variation in teacher preparation: How well do different pathways prepare teachers to teach? Journal of Teacher Education, 53(4), 286-302. http://dx.doi.org/10.1177/0022487102053004002

Davis, J., \& Wilson, S. M. (2000). Principals' efforts to empower teachers: Effects on teacher motivation and job satisfaction and stress. The Clearing House, 73, 349-353. http://dx.doi.org/10.1080/00098650009599442

De Jesus, S. N., \& Lens, W. (2005). An integrated model for the study of teacher motivation. Applied Psychology: An International Review, 54, 119-134. http://dx.doi.org/10.1111/j.1464-0597.2005.00199.x

Deci, E. L., \& Ryan, R. M. (2000). The "what" and "why" of goal pursuits: Human needs and the self-determination of behavior. Psychological Inquiry, 11, 227-268. http://dx.doi.org/10.1207/S15327965PLI1104_01

Deci, E. L., Connell, J. P., \& Ryan, R. M. (1989). Self-determination in a work organization. Journal of Applied Psychology, 74, 580-590. http://dx.doi.org/10.1037/0021-9010.74.4.580

Feng, L. (2005). Hire today, gone tomorrow: The determinants of attrition among public school teachers (Doctoral dissertation, Florida State University, Gainesville, Florida).

Fokkens-Bruinsma, M., \& Canrinus, E. T. (2012). Adaptive and maladaptive motives for becoming a teacher. Journal of Education for Teaching, 38(1), 3-19.

Gagne, M., \& Deci, E. L. (2005). Self-determination theory and work motivation. Journal of Organizational Behavior, 26, 331-362. http://dx.doi.org/10.1002/job.322

Hackett, R. D., Lapierre, L. M., \& Hausdorf, P. A. (2001). Understanding the links between work commitment constructs. Journal of Vocational Behavior, 58(3), 392-413. http://dx.doi.org/10.1006/jvbe.2000.1776

Ingersoll, R. M. (2003). Is there really a teacher shortage? Washington: Center for the Study of Teaching and Policy.

Jalongo, M. R., \& Heider, K. (2006). Teacher attrition: An issue of national concern. Early Childhood Education Journal, 33(6), 379-380. http://dx.doi.org/10.1007/s10643-006-0122-y

Krecic, M. J., \& Grmek, M. I. (2005). The reasons students choose teaching professions. Educational Studies, 31(3), 265-274. http://dx.doi.org/10.1080/03055690500236449

Kyriacou, C., \& Coulthard, M. (2000). Undergraduates' views of teaching as a career choice. Journal of Education for Teaching: International Research and Pedagogy, 26(2), 117-126. http://dx.doi.org/10.1080/02607470050127036

Kyriacou, C., \& Kunc, R. (2007). Beginning teachers' expectations of teaching. Teaching and Teacher Education, 23(8), 1246-1257. http://dx.doi.org/10.1016/j.tate.2006.06.002

Low, E. L., Lim, S., K., Ch'ng, A., \& Goh, K. C. (2011). Pre-service teachers' reasons for choosing teaching as a

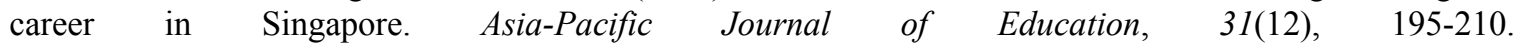
http://dx.doi.org/10.1080/02188791.2011.567441

Manuel, J., \& Brindley, S. (2005). The call to teach: Identifying pre-service teachers' motivations, expectations and key experiences during initial teacher education in Australia and the United Kingdom. English in Australia, 144 (2005), 38-49. 
Manuel, J., \& Hughes, J. (2006). 'It has always been my dream': Exploring pre-service teachers' motivations for choosing to teach. Teacher Development: An International Journal of Teachers' Professional Development, 10(1), 5-24. http://dx.doi.org/10.1080/13664530600587311

Marvel, J., Lyter, D., \& Peltola, P. (2007). Teacher attrition and mobility: Results from the 2004-2005 teacher follow-up survey. National Center for Education Statistics, Washington D.C.

Meyer, J. P., Becker, T. E., \& Vandenberghe, C. (2004). Employee commitment and motivation: A conceptual analysis and integrative model. Journal of Applied Psychology, 89, 991-1007. http://dx.doi.org/10.1037/0021-9010.89.6.991

Moran, A., Kilpatrick, R., Abbot, L., Dallat, J., \& McClune, B. (2001). Training to teach: Motivating factors and implication for recruitment. Evaluation \& Research in Education, 15(1), 17-32. http://dx.doi.org/10.1080/09500790108666980

Organisation for Economic Co-operation and Development (OECD). (2005). Teachers matter: Attracting, developing, and retaining effective teachers. Paris: OECD.

Richardson, P. W., \& Watt, H. M. G. (2006). Who chooses teaching and why? Profiling characteristics and motivations across three Australian universities. Asia-Pacific Journal of Teacher Education, 34(1), 27-56. http://dx.doi.org/10.1080/13598660500480290

Saban, A. (2003). A Turkish profile of prospective elementary school teachers and their views of teaching. Teaching and Teacher Education, 19, 829-846. http://dx.doi.org/10.1016/j.tate.2003.03.004

Sinclair, C. (2008). Initial and changing student teacher motivation and commitment to teaching. Asia-Pacific Journal of Teacher Education, 36(2), 79-104. http://dx.doi.org/10.1080/13598660801971658

Skaalvik, E. M., \& Skaalvik, S. (2008). Trivsel, utbrenthet og mestringsforventning hos lærere: En utfordring for skoleledere. [Satisfaction, burnout and self-efficacy among teachers: A challenge for school leaders]. In R. A. Andreassen, E. J. Irgens, \& E. M. Skaalvik (Eds.), Skoleledelse. Betingelser for laering og ledelse $i$ skolen [Management in schools. Conditions for learning and management in school] (pp. 141-152). Trondheim: Tapir Akademisk Forlag.

Spear, M., Gould, K., \& Lee, B. (2000). Who would be a teacher? A review of factors motivating and de-motivating prospective and practising teachers. NFER, Slough.

Stoeber, J., \& Rennert, D. (2008). Perfectionism in school teachers: Relations with stress appraisals, coping styles, and burnout. Anxiety, Stress \& Coping, 21(1), 37-53. http://dx.doi.org/10.1080/10615800701742461

Wang, H. H. (2004). Why teach science? Graduate science students' perceived motivations for choosing teaching as a career in Taiwan. International Journal of Science Education, 26(1), 113-128. http://dx.doi.org/10.1080/0950069032000070243

Watt, H. M. G., \& Richardson, P. P. W. (2007). Motivational factors influencing teaching as a career choice: Development and validation of the FIT-choice scale. Journal of Experimental Education, 75(3), 167-202. http://dx.doi.org/10.3200/JEXE.75.3.167-202

Yong, C. S. (1995). Teacher trainees' motives for entering into a teaching career in Brunei Darussalam. Teaching and Teacher Education, 11(3), 275-280. http://dx.doi.org/10.1016/0742-051X(94)00023-Y

\section{Copyrights}

Copyright for this article is retained by the author(s), with first publication rights granted to the journal.

This is an open-access article distributed under the terms and conditions of the Creative Commons Attribution license (http://creativecommons.org/licenses/by/3.0/). 